egter wesenlik anders as die vorige bedeling. So ook is die aard van die aansporings, wat baie meer sin vir die beleggersakeman as vantevore makk.

Daar moet dus ' $n$ heelwat groter kans vir die huidige desentralisasiebeleid wees om beter resultate te behaal. Dit is egter gebiedend noodsaaklik dat die Ontwikkelingsbank gestalte kry en begin funksioneer. Verder sal die politieke dialoog binne die raamwerk van 'n konstellasie van SuiderAfrikaanse state intens en gereeld moet voortgaan. Bo alles sal daar ' $n$ geloof by al die moontlike betrokkenes geskep moet word dat dit hier werklik om 'n langtermynstrategie gaan wat gereeld weer geëvalueer en, waar nodig, aangepas sal word en wat terselfdertyd ook met die Republiek van Suid-Afrika se ontwikkelingstrategie ingefaseer is.

Koördinasie van besluite, uitsprake en optrede in hierdie verband deur alle betrokke regeringsleiers is absoluut noodsaaklik vir goeie resultate. Die investeringsbesluite wat geneem sal word, skep betrokkenheid en het te doen met risiko's wat oor betreklik lang termyne strek. Om 'n hoë persentasie van daardie besluite positief te laat uitdraai, sal die streeksontwikkelingstrategie en die nywerheidsdesentralisasiebeleid altyd die hoogste mate van geloofwaardigheid moet hê; en dit sal boonop 'n sigbare geloofwaardigheid moet wees.

\section{Negotiating techniques}

\author{
P.J. Liebenberg \\ Executive Chairman, Finansbank Limited
}

Address delivered by Mr. P.J. Liebenberg, Executive chairman, Finansbank Limited, Johannesburg.

Henry Kissinger who is probably one of the most experienced negotiators in the world is on record as saying, 'the way negotiations are carried out is almost as important as what is being negotiated.'

I propose today to discuss the way negotiations should be undertaken but at the outset I must make it perfectly clear that there is no simple way, no definitive one way, no absolute way because although different negotiations might reveal common patterns every negotiation is different. These differences arise not only from the fact that every business deal is a new venture with its own characteristics but also because in the process of negotiating one is dealing with different people, people with their own personalities, characteristics, mannerisms, twists of mind. The many permutations which all these factors bring about mean that every negotiation is a new experience and the big advantage which an accomplished negotiator has over the untried negotiator is that he has developed an intuition which enables him to anticipate, to be flexible and to recognize the mental processes of the people he is dealing with.

Therefore, I cannot give you an $A B C$ in the art of negotiation. There is simply no way whereby I can impart to you sufficient knowledge to enable you to become suc. cessful negotiators in one easy lesson. All that I can do is outline basic principles which I hope will be of help to you should you find yourselves as part of the negotiating process in the broad field of mergers and acquisitions.

No negotiation can take place, let alone succeed, unless the ground work has been done and uniess one is thoroughly schooled in the need to prepare one's case.

The first step that a negotiator must be able to do is to identify what the basic facts are. What do you really want out of the negotiation and at all times these basics must be clearly held in one's mind and never lost sight of. This fundamental principle applies with equal emphasis whether one is the aggressor or the victim in a takeover situation.

Before you go anywhere near the negotiating room you must examine your case and clearly identify your strengths and your weaknesses. There is never a negotiation with one single clear-cut proposition. There is, of course, one definitive end - to buy and to sell - and in the end result a negotiation hinges on price. How much the aggressor or buyer is prepared to pay and at what price the seller is prepared to relinquish his property. But these factors often. are hedged in with a large number of side issues and it is imperative that the negotiator clears his mind so that in recognizing the side issues he never loses sight of the main purpose.

I make a practice of listing all the points involved. Those which appear relevant and those which might appear not to be so relevant. These points must be studied carefully so that by a process of elimination those factors which are important and basic to the deal are given priority. The rest must be recognized, perhaps used as negotiating counters or discarded as concessions as the negotiation goes through its various stages of development.

It is necessary not only to examine your own case but to try to identify your opposition's position as clearly as your own. On the other hand one must never enter a negotiating room with any sharp preconceived ideas about the opposition case. While you are looking for his strengths and weaknesses you must constantly be aware that these can change in the environment of the negotiating process. You must be prepared to be flexible, not only in negotiation but also in the attitudes you might have to adopt in the course of negotiation.

When you have made your lists of strengths and weaknesses and when you have made your lists of priorities - in your case as well as that for your opponent - it is useful to discuss the deal with your principal, with your colleagues, not only to clarify your own thinking, but also to go through an informal game play so that your attitude to the deal is sharpened. This enables you to see your objectives in clear perspective so that you can develop the persuasive arguments which are part and parcel of the negotiating process. While, as I have said, no two negotiations are alike, this game play enables one to recognize precedents that might be applicable in the task at hand.

It should be remembered that one never goes to the negotiating table without some preliminary steps having already been taken. No negotiation starts cold. These preliminary steps show clearly whether the posibilities exist 
for a deal. It's either on or it's off. And if it is on it means that both parties are prepared to talk, both parties have established that they have something in common, that both parties are interested in finding some common solution which is agreeable to both. In other words there are certain broad parameters in which one can work. At the outset it might seem that these are two points at either end of the diameter of a circle and the course and trend of negotiation is to try to bring them closer together. To accomplish this there must be give and take. It might be in the cash element, it might be in the personalities involved, it might be in the handling of staff. There are many areas which have to be explored. Some of these might be side issues, some of these might be germane to the principles under discussion. This is why it is so essential always to keep one's basic objectives in mind so that one is not bogged down in a discussion of side issues which might assume a false importance if one is not careful.

Usually the first round of talks in any negotiation is a preliminary stating of views and testing of personalities. This is very much like the first round in a boxing match in which the opponents are sizing each other up, testing each other's skills, tactics, defences and generally measuring up the worth of the other man. Both sides state their cases in broad outline. It is a formal meeting, an exploratory meeting, usually with no give and take and very often ends on a note which indicates that there is a proposition to negotiate and that each side will examine the viewpoints of the other. It is from this stage on that the role of the negotiator becomes intense. Arising from the preliminary discussion he must try to ascertain exactly what the other side is looking for. He must adjust his pre-negotiation stance to what the other side really wants as opposed to what he thought they might want and he must prepare himself for the second round of talks which is often crucial although it is very rare that it could become definitive.

Because the initial stages of negotiation are tentative I do not believe that my client should participate personally. I find that there are many advantages in keeping him in the background. There are many reasons for this. Let me mention a few.

First, as a negotiator I prefer to handle the discussions even though I might have colleagues with me to clarify any technical points that might arise. If the client is present there is always the tendency for the other side to address him and if he is not experienced in the art of negotiation he might be drawn into discussions which could result in an unwarranted concession being made.

There is another important factor that always has to be taken into account. One's client is emotionally involved in any negotiation. He stands to gain or lose and at all times he is inclined to be subjective. This is one weakness that must never be allowed to emerge in the negotiating process. Subjectivity can be dangerous because one loses control and emotions might surface at a time when objectivity is the name of the game. At no time dare the negotiator lose objectivity. He must keep his objectives always in the fore part of his mind. He must listen to the arguments of his opponents with cold and analytical concentration and measure them up against his own list of priorities. He must never be over eager and appear ready to make concessions at an inappropriate time. The client on the other hand sensing victory might blurt our a proposal which could be to his ultimate disadvantage.

I always feel that it is the duty of the professional negotiator to shield and protect his client, not only from his own potential weaknesses, but also from exposure which could be a serious handicap to the outcome. In any case it is a useful negotiating technique to be able to defer a negotiation at a difficult moment by indicating that the point under discussion has to be referred back to the client. This is particularly appropriate when the opposition raises a new point which requires careful study.

A reference back to the client can make a situation of deadlock appear to be the opportunity for a further meeting rather than the deadlock that it is. Not that deadlock is not a useful negotiating ploy. It is a technique which must be used with care and with discrimination. There are times in a negotiation particularly when one feels that one has one's opponent in the corner that one contrives to create a deadlock which will force one's adversary to come back again. It can reveal a weakness which one is trying to exploit. But I must emphasize that this is a device which only the skilled negotiator may start to use with advantage.

Few negotiations proceed smoothly and quickly. The normal pattern can stretch over weeks, often months with very few negotiations running easily towards a conclusion. If the seller gives in too quickly one immediately starts to wonder what is he hiding? Why is he too eager? Is the buyer paying too high a price? Very often a hastily concluded negotiation can come unstuck. It is better always to move patiently towards a deal and then away from it, towards and away, again and again. In this way the other party alternates between the pleasure of seeing his objective within reach and then the anxiety of watching it slip away. It is a strategy that works but I must warn that it does entail risk and like the technique of deadlock, judging the extent of the risk is part of an experienced negotiator's ability.

I mentioned a few moments ago that there are times when one pushes one's opponent into a corner. This one can do but one must never allow one's adversary to feel trapped. A trapped opponent might walk away from a desirable deal or force him into a temporary agreement that can come unstuck. The only agreement which holds fast is one in which both sides feel that they have concluded a beneficial deal. They might have started at the far ends of the circle and by a series of compromises and concessions they have both got out of it a fair measure of what they had hoped for when negotiations had started. Never lose sight of the fact that in every negotiation the outcome is essentially one of compromise and it is up to the negotiator to effect his compromise to the best interests of his client.

When sitting around the negotiating table it is inadvisable to do all the talking. A good negotiator must be a good listener. To try to dominate the negotiating table with a flood of words is to submerge the other side's point of view and only by hearing the other side out can one ascertain the real nitty gritty of the deal under discussion. Not only must the negotiator be a good listener but he must also be an acute observer. He must be a student of body language. 
He must be able to identify from the other side's facial expressions, gestures and changes of mood whether his arguments have made a telling point or not. There are many times when I have detected an almost imperceptible change of look in a person's eyes and have known that a deal is on its way to a successful conclusion. By the same token I have also judged by the same means that a deal is doomed to failure.

It is through one's observations at the negotiation table that one can recognize whether one is dealing with sincere people of integrity or whether one is dealing with chancers and rogues. No one should waste his time with this latter type. Negotiation must be carried out by people who have integrity, who say what they mean and who do not perpetually take backward steps. Either one is negotiating on a practical basis or one is not. There must be firm ground. It is almost impossible to deal with people who switch and change and who do not have their objectives clearly in mind.

During the course of the negotiation process it is often advisable to reiterate from time to time the points of agreement. This not only fixes these points firmly in one's opponent's mind but it also enables the negotiator to restate his basic objectives and to clear the air of the many side issues which arise in every negotiation, even when dealing with people who are skilled in the art.

I have said that the good negotiator knows how to keep silent but this does not mean that he must sit like a dummy. On the contrary when he is not putting forward his own arguments he must lead the other side so that they are doing the talking, but they are talking to his dictate. In other words there are many advantages in posing questions. They might be general or specific questions, they can be leading questions to draw points of view and to reveal what the real objectives of the other side really are. On the other hand, one can put questions that demand a choice. There is nothing so revealing as to throw provocative questions at an opponent and so force him to reveal his hand when he is off guard. The effectiveness of questions in any negotiation are directly proportionate to the negotiator's experience in using them.

The intelligent asking of questions goes a long way towards ascertaining the real needs of the opposite side and in any negotiations one has to ferret out what the other side really needs. And there is a marked differentiation between need and want. Both parties in a negotiation want the most they can get out of it but need is at a lower level and what one must aim for is to achieve need and satisfaction. Negotiation presupposes that both negotiator and his opposer want something but what one has to aim at is to ascertain the real needs of both parties.

To ascertain these real needs is part and parcel of the tactics that one employs during the course of a negotiation. As I have said, one asks questions - one probes - one tries to penetrate the defences which your opponent raises from time to time, even if he is the aggressor, in order to conceal some of the advantages that he wants to get out of the deal. But a negotiation cannot succeed by employing tactics alone. One must have an overall clear strategy in mind. One must go, like a general into battle, with a clearcut perception of aims, objectives and how to get there. One must know what one is prepared to yield and what aspects of a deal are really non-negotiable. But one must never concentrate on the non-negotiable aspects of the deal. If one did no negotiation would ever succeed. It is the negotiable elements on which one must concentrate. It is imperative to be flexible in the choice of one's tactics. Tactics which are right for one man are wrong for another. Tactics that might be appropriate for the start of a negotiation may well be unsuitable later on. There must be a continuous reassessment of the tactics which one employs, and the experienced negotiator, who has learnt the trick of watching himself almost at arm's length during negotiating sessions, is continually analysing the effects of his tactical ploys. Can they be changed? How will the other party react or interpret these tactics? Will they backfire on me?

The choice of tactics involves ethical questions. Ends do not justify means in business and at no time in the course of the negotiating process is there room for unethical behaviour. Unless ethical standards are rigidly maintained the ultimate goal can be destroyed. There is a golden rule about employing tactics: they should never be used unless the negotiator has considered what counter measures the other man is likely to take. If his reaction is to take it or leave it you might reach a point of rupture and if the negotiation is desirable one does not want to lose the game because of an ill-considered move.

On the other hand if you are an experienced negotiator there might be a time when you, having established yourself in a dominant position, might revert to the 'take it or leave it' tactics. You might resort to this device when you don't want to encourage any further haggling about nonessential details, or when you have reached the hard rock basis of the deal and you cannot afford to make any more concessions. Then you are using 'take it or leave it' as your last word. Perhaps an appreciation of take it or leave it is a reasonable illustration of how to employ the tactical approach during the course of negotiation. And when the other side tries to use this strategem, what is your reaction? You can walk out. You can ask your opponents to put their offer in writing as a final offer or, if you don't want the negotiation to fall through, you can talk on as though you never heard it at all. Trace a course back to the point when the other side appear to have made an irrevocable decision and skilfully you lead the opposition towards a new direction. In other words you divert them away from what might have been a breakdown point.

I have often been asked whether one uses different strategies and different tactics when acting as the aggressor in a negotiation from those which one might use when acting as the counsel for the defendant. While there are certain superficial differences, the aim of the negotiator is the same in both cases - and that is to get the best possible deal. When one is planning in the takeover situation, one knows exactly what one wants. The would-be buyer is seeking to take over or merge with another business for very definite reasons. One is looking for the immediate acquisition of assets which could increase a business, enhance productive facilities or further penetrate a market without the cost of time that expanding an existing business would take. In other words after having thoroughly studied a situation the 
aggressor goes into a negotiation with clearly determined objectives. He knows what he wants and he knows approximately what the cost might be and he has a shrewd idea of what he can afford to pay in relation to the benefits which might accrue.

The unknowns are the real wants and needs of the other side. As a buyer, as the aggressor, one is in the position to take the initiative. On the other hand one must not be stridently aggressive in one's approach. I always feel that I might disadvantage my case by putting the other side on the defensive. My strategy is aimed at making the other side react so that $\mathrm{I}$ can ascertain what they are seeking from a deal so that we can get down to the fundamental of price, structure and the personal security of all the people involved. My case must be one of trying to prove the advantages which will accrue from such a deal. And it must be remembered that unless there are advantages for both sides a deal cannot stick, it will fall apart. In other words the case must be presented positively and my response to the other side is to try to show that objections to a deal are not valid. This is obviousiy all a matter of personal style and preferences.

On the other hand, when I appear on behalf of a victim company, I do not believe in adopting a passive defence. The mere fact that we are sitting logether around the negotiating table is in itself evidence that we are interested in a deal. Therefore, my ploy must be to try to get the maximum out of that deal that I can achieve for my client. In negotiation, as in other situations, attack is the best form of defence. I must analyse the conditions and the propositions that have been put forward. I must denigrate the so called advantages spelt out by the other side and I must emphasize the strengths of my own case. These tactics must be used in order to squeeze out of the deal the utmost that I can for the benefit of my client. I know that the predator company needs me or rather needs my client's business. If he didn't he wouldn't be sitting around the table with me. What $I$ as a negotiator must try to ascertain is how far he is prepared to go and whether this matches my client's expectations of what he hopes to get out of the deal.

But no matter whether I am acting on behalf of a predator company or a victim company I have one immutable principle: I try to maintain effective control of the negotiating process. I have found from past experience that the moment a negotiator allows himself to be cast into a secondary role he loses ground and yields instead of taking. Taking control means exerting your personality and impressing it on the other side. One does not have to be aggressive, one does not have to be noisily dominating. One has to use a superior logic and to apply it persuasively. The art of negotiation is the art of persuasion. You have to persuade people by sheer weight of reason that you are right. But in doing so one must tread carefully. While you are right, or rather while you are trying to convince people that you are right, you must not leave them with the impression that they are wrong. That is the surest way to a deadlock. This is where there is a tremendous subtlety. You must convince people that you are more right than they are. Never never make the other side feel that they are coming second. The successful negotiation is one in which both sides believe that they have achieved a victory. And it is your job as a negotiator to win more of the fruits of victory than the other side.

In conclusion I would like to read the following quotation from an essay written by Sir Francis Bacon, Lord Chancellor of England in the sixteenth century on the subject of negotiation:

'If you would work any man, you must either know his nature and fashion, and so lead him; or his ends, and so persuade him; or his weakness and disadvantages, and so awe him; or those that have interest in him, and so govern him. In dealing with cunning persons, we must ever consider their ends, to interpret their speeches, and it is good to say little to them, and that which they least look for. In all negotiations of difficulty, a man may not look to sow and reap at once; but must prepare business, and so ripen it by degrees.'

The seven most important characteristics of a successful negotiator (USA survey):

(a) Never lose sight of the main issues;

(b) Never lose flexibility;

(c) Never ignore the need for preparation;

(d) Never tell a lie;

(e) Never try to be 'too clever by half';

(f) Never act in an insincere way; and

(g) Never become impatient.

\section{Bestuursleiding}

\section{F.J.H. Le Riche}

Sentrachem, Marshalliown, Johannesburg

1982 Sertifikaatoorhandigingsfunksie van die skool vir Bedryfsleiding van die Universiteit van Suid-Afrika ter viering van die voltooiing van die sewende Bestuursopleidingsprogram deur die studente in 1981

Die sakewêreld is gestrengel in 'n hele proses van verander ing. Sy vindingrykheid en navorsing is grootliks verantwoordelik vir sy tegnologiese agtergrond en vir kommersiële suksesse wat hy van tyd tot tyd behaal.

Dit is die taak van die bestuurder in die sakewêreld om die probleem wat deur hierdie vinnige veranderende omstandighede teweeggebring word, uit te pluis en dan verantwoordelik te wees vir die beplanning van die saak se medium- en langtermyntoekoms. Terwyl verandering 'n voorvereiste is vir materiële vooruitgang, bly die entrepreneur se taak die skepping van ekonomiese groei wat inpas by die omgewing waarin die saak wat hy bestuur moet voortbestaan. Hierdie omgewing word hoof saaklik aangedui deur ekonomiese klimaat, mense, staatsinmenging, vakbonde, nywerheid en in die algemeen die publiek wat optree as verbruiker in sy grootste vorm.

Die bestuurder op alle vlakke se primêre taak bly dieselfde. Ek glo nie dat daar 'n verskil in die aktiwiteite en beginsels van bestuur is nie - of jy nou ook' $n$ besturen 